\title{
Chapter 4 \\ Digital Transformation in Higher Education Institutions as a Driver of Social Oriented Innovations
}

\author{
Vladislav Kaputa, Erika Loučanová, and Fernando A. Tejerina-Gaite
}

\begin{abstract}
Higher education institutions have in the digital transformation an opportunity to facilitate access to education for individuals of different social backgrounds. At the same time, it will provide them with the necessary tools and skills to face current global problems (poverty, health quality, income disparities, environmental crises, among others) from a transdisciplinary perspective. Progress in the digitalization of higher education has been significantly accelerated by the onset of a pandemics in early 2020 (in European conditions). Such a rapid and massive transition to distance (online) education with comprehensive support for digital technologies is unparalleled. The survey conducted reflects the consequences of this change. Results shows that digital transformation improves some of the most demanded skills in the new knowledge society (searching and processing information, digital communication and socialization or working with text). Likewise, it has an important role in reducing costs related to education, but also in degradation of abilities in personal communication.
\end{abstract}

Keywords Digital transformation · Higher education institutions (HEIs) - Social innovation · Distance education · Pandemics

\section{The Key Points of the Chapter Are the Following}

- To understand the concept of Digital Transformation and its social dimension.

- To identify the main challenges facing universities in the digital era.

- To clarify the relationship between Digital Transformation and Social Innovation.

\footnotetext{
V. Kaputa $(\bowtie) \cdot$ E. Loučanová

Technical University in Zvolen, Zvolen, Slovakia

e-mail: kaputa@tuzvo.sk; loucanova@tuzvo.sk

F. A. Tejerina-Gaite

University of Valladolid, Economics School, Valladolid, Spain

e-mail: ftejerina@efc.uva.es 
- To understand the role of digital tools in fostering the social dimension of higher education institutions.

- To verify whether the accelerated application of digital learning has favoured the social dimension of this innovative pedagogical method.

\section{Introduction}

We live in a rapidly changing, hyper-connected world and face increasingly global, complex, and dynamic problem situations, such as poverty, income disparities, environmental crises, organized crime, and health quality problems. These complex or "bad" problems are not caused by just one field of society (Kaputa et al., 2020a, b) and cannot be adequately solved through one scientific discipline (Rittel \& Webber, 1973; Özbekhan, 1970) but comprehensively, through the cooperation of several partnerships.

Higher education institutions (HEIs), as providers of knowledge, take on a leading role in activating a public-private partnership. Partnership is now becoming a necessary and at the same time dynamic element of development and innovation based on the knowledge economy. It enables the involvement of the whole spectrum of the organization's actors in decision-making on development activities. It contributes to the fact that organizations can adopt new ideas, expand their knowledge and constantly learn, which can ultimately also contribute to significant support for innovation as such.

The biggest challenge today is pandemics, and its impact significantly affects various areas of our lives. Innovation in this situation is a means and a tool to mitigate the effects of a pandemic on all stakeholders. The most important is the nature of innovation - that it should lead to the creation of something new, the improvement and change of the current situation (Pavie \& Carthy, 2015), as well as problem solving and increasing competitiveness based on the knowledge economy. Social innovation is important in this situation in education. Social innovations aim to create value for society. The drivers of social innovations can come from many different backgrounds, including civil society, entrepreneurs, government, public institutions, and universities. Universities around the world have started to create a learning environment that allows students not only to acquire knowledge and skills needed in their respective subject areas, but also the necessary tools to make a difference (Russo \& Mueller, 2013).

This chapter introduces the theoretical concepts of the digital transformation and social innovations in HEIs. It aims to evaluate the digital transformation of HEI on the basis of research of students' attitudes after their experience with distance education during pandemics. Subsequently, social innovations are discussed in the context of the ongoing digital transformation of HEIs. 


\section{Digital Transformation}

In recent years, digital transformation (DT) has emerged as an important phenomenon that attracts the attention of both researchers and practitioners. Nevertheless, we currently lack a comprehensive understanding of this topic. At the macro level, DT refers to the changes experienced by institutions and society in general as a consequence of the use of new digital technologies (Vial, 2019). At the organisational level, companies can find ways to innovate with these technologies by developing strategies that embrace the implications of digital transformation and drive better operational performance (Hess et al., 2016).

The DT is deeply connected to the so-called fourth industrial revolution, a process through which digital technologies are shaping the future society and economic development in a comparable manner to the case of steam power for the first industrial revolution (Schwab, 2016). DT is the engine of the fourth revolution, the digital revolution. The literature on information technologies and its consequences on organisational transformation, may be seen as one of the scholarly roots of DT research (Nadkarni \& Prügl, 2021). Recently, Vial (2019) analysed more than twenty definitions of the term DT and tried to identify their essential features by proposing to define DT as a process that aims to improve an entity by triggering significant changes to its properties through combinations of information, computing, communication, and connectivity technologies.

However, DT is more than merely migrating paper records to a computer, and it is more than adopting technologies to perform business operations faster and more efficiently (Brooks \& McCormack, 2020). In this respect, DT is a series of deep and coordinated culture, workforce, and technology shifts that enable new educational and operating models and transform an institution's business model, strategic directions, and value positions. Thus, it is not just about disruption or technology, it has to do with the fact that technology and digitalization are becoming a basic necessity for the society (Curaj et al., 2018), meaning a significant change in terms of people's jobs and skills, the type of work they do, aiming to significantly impact all aspects of human life (Grosseck et al., 2020). In this vein, some definitions take a broader perspective. According to OECD (2019a) digital transformation is the result of digitization and digitalization of economies and societies. It is a process involving several digital technologies, from $5 \mathrm{G}$ to artificial intelligence, big data and blockchain. These technologies form an ecosystem through which future economic and social changes will arise. In general, the different definitions of DT may be categorized in three distinct elements (Reis et al., 2018): (1) Technological, DT is based on the use of new digital technologies; (2) Organizational, DT requires a change of organizational processes or the creation of new business models; and (3) Social, since DT is a phenomenon that is influencing all aspects of human life.

The DT is the new opportunity for business and renewal strategies for any organization, company or institution that arise from the emergence, development and use of new technologies. A scenario that also demands new attitudes and skills both in individuals and in organisations and institutions. Therefore, the DT is not 
focused on the technology used (big data, artificial intelligence, the internet of things, cloud computing, mobility, connectivity, 3D printing, social business, etc.), but on using it to achieve new objectives based on innovation and creativity, which could not be achieved without them. DT is linked to business objectives and strategies. The digital transformation means that digital uses, beyond the improvements and support of traditional methods, allow or encourage new forms of innovation and creativity, both in business and in society in general: government, education, global communications, health, art, science.

\subsection{Digital Transformation in HEIs}

Never, during the millennium since the founding (1088) of the University of Bologna, has the university been so radically and urgently challenged as it is today, as a consequence of the digital revolution that has induced a new sociotechnological scenario: global, competitive, dynamic, internationalised and digital, in which it must develop its activity. It must do so in competition with new agentsinstitutions, companies and individual experts (icons) with millions of followers, with extraordinary power of attraction-which with the rise of new technologies provide and exchange new knowledge. This, together with the new generations, already digital, demanding training, means that new actors have considered a golden opportunity to create networks, share and create knowledge, train and certify knowledge and skills. For this reason, the university is obliged to accelerate the transformation required by the digital revolution, its digital transformation.

According to Rampelt et al. (2019), DT influences all activities of HEIs. It permeates all processes, places, formats and objectives of teaching, learning, researching and working in higher education. This transformation includes the development of new infrastructures and the increasing use of digital media and technologies for teaching and learning, research, support services, administration and communication, but also the need of students and staff to develop new digital skills for their current and future workplaces.

The university is an institution that has always been committed to knowledge, education and training. Throughout history, it has taken on new functions and missions induced by the sometimes disruptive changes experienced by society.

The industrial revolution, especially in the middle of the nineteenth century, reveals the importance of knowledge for the industrial development and prosperity of nations, and calls for the need to transfer new knowledge, generated in universities, institutes and research laboratories, to the business and productive fabric for its application, to generate innovation, economic value and social development. After the equator of the twentieth century, the knowledge society replaces the value-work binomial with the value-knowledge binomial, and elevates knowledge to the condition of social good, which is necessary (socially obligatory) to produce, disseminate, transfer and apply in order to generate economic development, cultural progress and advance in social cohesion. 
In this context, the global competition for knowledge economy together with the dominant roles of the digital connective tools is forcing the HEIs to evaluate their current structures and take drastic decisions to improve these structures to better suit the needs and requirements of the twenty-first century (Odabasi et al., 2010).

In a comprehensive literature review, Castro et al. (2020) provide a systematic analysis covering 19 academic studies about the DT in higher education institutions (HEIs) from 2016 to 2019. They identify three perspectives: Technological, organizational and social. The tendency has evolved over time, from the technological view, then organizational, to finally consolidate in the social perspective. In the same way, they show the dimensions, which within a HEI, have received the DT or have been forced to intervene in DT processes. The most influenced dimensions by technologies intervention are teaching, infrastructure, curriculum, and administration, well above research, business process, human resource or digital transformation governance. Finally, they emphasise teachers and students as the main actors. On this matter, Brooks and McCormack (2020) carry out a survey about DT in HEIs. They find that six of the top seven major benefits of DT that respondents highlighted are directly related with student success.

\subsection{Challenges of the Digital Age for Universities}

Higher education institutions should set up in their strategies clear and specific goals towards their DT. Universities need a strategic vision that allows the whole institution to join efforts in the implementation of the digital initiatives. For doing so it is important to have a strong leadership and a specialized team that can confidently explain and implement their plans. A clear vision will make the team and stakeholders more involved and invested in the process of digital transformation (Rodrigues, 2017). Only institutional conviction of the need to exploit the boost of the digital revolution and the solid commitment of students, professors, researchers, staff and managers, will allow the university to be successful in the digital era. This process entails the digital infrastructure growth, the development of the academic staff's skills to use digital methods in their teaching and the improvement of its students' digital skills, as well as other significant challenges among which we emphasized the knowledge leadership and pedagogical and curricula changes.

Knowledge Leadership The educational paradigm, which rests on the conditions and requirements of the industrial age, appears to fall short in terms of meeting the needs and demands of the twenty-first century learner. The emerging digital connective technologies and the educational innovations they triggered are disrupting learning processes and structures of the industrial age such that it is now an imperative to develop a new educational paradigm (Saykili, 2019).

In the current digital age, new actors are emerging that are capable of fulfilling the functions of guiding the learning of others, improving and expanding the knowledge available and sharing it through technological platforms. Companies have not 
hesitated to integrate themselves into this new global and digital ecosystem and are exploring and exploiting the opportunity provided by the network to promote and exploit knowledge in conditions unimaginable until now, as well as to accredit knowledge, skills and competences. As a result, we can see the increase in social and business acceptance of the certification or degree given by companies and non-university institutions, and even by specially recognized experts. Nowadays a Google certification in certain fields-digital marketing, for example-is as valuable as a university certification.

Therefore, the university must accelerate its digital transformation, the transformation induced, driven and supported by the technological revolution, which will allow, on the one hand, to take advantage of the enormous potential offered by the field of educational technology and, on the other, to offer new generations of students from anywhere in the world, new educational opportunities and training, as well as to provide new training and accreditation alternatives to professionals in the social, administrative, business and industrial sectors.

Pedagogical Methodologies and Curricula Changes The new economy, based on knowledge and information is generating new employment niches. It is estimated that around $65 \%$ of the primary school children today will work in jobs that do not exist now (Şahin \& Alkan, 2016). To perform the new jobs, training in digital skills is not a requirement but a must, because digital technology is not the future, is present. In addition, the learner profiles are changing and diversifying (Saykili, 2019). An increasing number of individuals perceive the need for further training in order to obtain the new knowledge and skills required in the digital age. Learners are more and more digital natives. They have already integrated digital tools in their daily life. Another change is the increased learner diversification. Learners with different demographics such as age, experience, culture and ethnics, learning styles and paces bring their distinct characteristics into learning environment, which poses new learning potentials and challenges for HEIs.

Consequently, the digital revolution means new challenges to the university: to provide training in digital skills and to accelerate the renewal of learning methods, especially face-to-face. In this regard, the emergence of digital technology has contributed to the revolution of classrooms and learning methods. The potential of digital technologies to enhance student learning has been well established. Benefits include the enhanced diversity of provision and equity of access to higher education, alongside the increased efficiency of delivery and personalization of learning processes (Henderson et al., 2017). DT drives a practical and creative education, incorporating new didactic models for students to learn and teachers to teach, such as Digital Cooperative Learning, Virtual Reality, Gamification and so on (Abad et al., 2020). Betting on creativity and entrepreneurship, the DT applied in education advocates establishing learning methods based on individualized training, personalization of content, and the development of one's own skills, through social learning (Jahnke \& Kumar, 2014).

Moreover, the great challenges of humanity today are global and complex problems-environment, climate change, health, food, migration, biodiversity, 
sustainable development, etc.-. Their solution, beyond the necessary social awareness and international political will, requires the integration, participation and contribution of more than one field of knowledge from a transdisciplinary perspective. This reality must be present in the university offer of curricular itineraries, so that the offer of classic or traditional itineraries must incorporate interdisciplinary ones, itineraries resulting from the interrelation between the different fields of knowledge.

This means, in a certain way, a change in the university education approach, which should have an increasingly intense focus on the study of problems and not so much on the study of disciplines, since society demands to solve problems and problems can transcend the limits of one discipline, requiring the concurrence of a variety of knowledge.

\section{Social Innovations in HEIs: The Role of the Digital Transformation}

While business innovation remains rooted in the world of commerce and competition, social innovation has as its starting point notions of social beneficence and public good that supports people in organisations, communities and society in general (Dawson \& Daniel, 2010; Loučanová et al., 2018). However, the concept of social innovation encompasses a wide variety of dimensions, so there is currently no generally accepted definition. As a result, the social innovation area is not yet well integrated and consolidated as a research field. This complicates the systematic accumulation of knowledge and growth of the emerging social innovation research field (van der Have \& Rubalcaba, 2016; Loučanová \& Nosálová, 2020). Authors such as Dawson and Daniel (2010), Van der Have and Rubalcaba (2016), Pol and Ville (2009) and Hsuan-Yu et al. (2019) carry out interesting reviews of the concept of social innovation.

In this regard, two types of definition of Social Innovation (SI) clearly emerge. On the one hand, a sociological oriented approach, which considers SI as new social practices created from collective, intentional, and goal-oriented actions aimed at prompting social change (Cajaiba-Santana, 2014). This perspective emphasizes on "social practices". The sociological component was present in the earliest approaches to the SI concept and has evolved to the present day. On the other hand, a more economic view, which defined SI as any innovation which has the potential to improve the quality and/or the quantity of life (Pol \& Ville, 2009). It focuses on the value created by the innovation and it is related to the ideas, services or new systemic transformations and associated social impacts. The latter is the perspective that has been adopted by different supranational organisations and is the one we will follow in this chapter.

Thus, the European Commission states that social innovation can be defined as the development and implementation of new ideas-products, services, and models - to meet social needs and create new social relationships or collaborations 
(European Commission, 2013). In this context, technology serves as an inherent element of SI (Reynoso et al., 2015). Social innovation can rely on technologies and lead to novel adaptations and developments in technology. Such innovations involve using new (or existing) technologies and knowledge in new ways in order to meet social goals and improve social circumstance (Dawson \& Daniel, 2010). Hence, SI is regarded as novel social technologies that create new social value (van der Have \& Rubalcaba, 2016). The team of authors who published the Handbook of SI (MIRRI SR, 2021) views them as innovations societal, which represent new, more efficient, effective, sustainable and fairer solutions to social problems and the fulfilment of social needs compared to available alternatives. They can include the creation of new products, services, the introduction of technology, but also the creation of new social processes, organizational structures, changes in set rules or the creation of new roles in the social system. Their goal is a qualitative change in the life of society.

\subsection{Social Innovation and the HEIs' Third Mission}

As noted above, social innovation is a concept of growing importance in both academia and society. Several authors (Jongbloed et al., 2008; Goddard \& Chatterton, 1999, among others) consider that greater exchange between universities and different interest groups demands a different type of commitment, the so-called third mission. This mission would focus on the university's contribution to social development and would complement the traditional functions of teaching and research. Therefore, among HEIs objectives we should add the purpose of leading change and improvement in individuals and the society in general. While technological innovation is a critical component of future economic growth, social innovation is equally important in building social capital and in improving life chances, for example through social inclusion, community building and higher-level skills development (Elliott, 2013). According to Jaeger and Kopper (2014), HEIs are considered to be key actors in regional innovation systems. The traditional missions of HEIs comprise (1) the generation and accumulation of academic knowledge, and (2) the diffusion of knowledge via academic education. Attention has also been drawn to the regional development role of HEI activities: their "third mission". The authors pointed out that the success of HEI's knowledge transfer is geographically unevenly distributed, with some regions being able to profit from knowledge transfer more effectively than others. Their research focused on an important factor influencing the success of knowledge transfer: the 'fit' between HEI and region. A close correlation between HEI's focus on education and research on the one hand and regional economic structure on the other hand might indicate a higher potential for the HEI's regional engagement and third mission activities.

New social innovations should consider the wider social context within which they are embedded, as well as to be based on the latest knowledge and research. This suggests that HEIs are perfectly placed to lead an inter-disciplinary focus on how best to solve or alleviate social problems (Hazenberg et al., 2019). Traditionally, 
third mission of the university has focused on the commercialization of knowledge through spin-offs, patents or forming relationships with firms and other stakeholders. In contrast, the so-called developmental university consider addressing societal needs as the primary mandate of the university's third mission (Arocena et al., 2018). Beyond knowledge and technology transfer, universities should seek to broaden the scope of university engagement in social innovation and inclusion. These concepts focus on democratizing knowledge through teaching and research, thereby reducing the knowledge gap (Arocena \& Sutz, 2017).

In this context, digital tools are offered as solutions to the aforementioned challenges that HEIs face today, as well as a great opportunity to enhance their social dimension. Thus, distance learning tools, online social networking tools, open educational resources, massive online open courses, sophisticated learning management systems, and so on, are seen as innovations that contribute to enabling equal educational opportunities for all, accessing quality educational content, and supporting lifelong learning (Saykili, 2019).

The Sorbonne Declaration (1998) already referred to the fact that students should be able to enter the academic world at any time in their professional life from diverse backgrounds. In addition, the social dimension of higher education has been exposed in terms of the need to reduce inequalities, raise social cohesion and enable participation for anyone with the appropriate qualifications and motivation, regardless of their social and economic background (Orr \& Mishra, 2015). The social commitment of universities must also be reflected in their determination to improve the employability of their graduates and the transformative power of education on individuals and the community.

However, the 2015 Bologna Implementation Report, among others, exposes that in general the European goal of providing equal opportunities to quality higher education is far from being reached. Similarly, little progress has been registered with regard to lifelong learning (European Commission, 2015). In this context, DT can be a powerful driver of social goals. According to Rampelt et al. (2018) the social dimension and the DT of higher education should not be approached as two isolated challenges, but rather as an opportunity to increase diversity and open up higher education through use of new technologies. Moreover, Orr et al. (2020) state that digitalization itself should be seen as a social innovation.

\subsection{Digital Learning}

Digital learning and distance education has emerged as a pivotal approach in disseminating social innovataion ideas and new knowledge (Bayuo et al., 2020). The process of using technology to offer training and education to vulnerable groups through less expensive methods has received attention in the literature. Key among the issues suggested is distance learning and lifelong learning (De Pretelt \& Hoyos, 2015) which make it possible to delivery quality education to remote areas using social innovation tools and software. 
Within the European context, the potential of DT for improving learning has been widely recognized. Certainly, the Yerevan Communiqué of 2015 (EHEA, 2015) set up that "we will encourage and support HEIs and staff in promoting pedagogical innovation in student-centred learning environments and in fully exploiting the potential benefits of digital technologies for learning and teaching". In the same vein, the European Commission in its "Digital Education Action Plan" established that the access and the use of digital technologies can help reduce the learning gap between students from high and low socioeconomic backgrounds (European Commission, 2018). Indeed, digital learning can significantly lower the cost of access to training and better meet individual needs according to their learning styles and skills (OECD, 2019a). Investing in digital learning will lead to knowledge democratization across borders while demystifying the elitist view of the university classroom. It offers lifelong education for workers who can upgrade their skills while working, thereby increasing their skills premium (Bayuo et al., 2020). The social dimension is therefore very much present, we can even say that it is the main catalyst, of the transition towards a more digital and open learning model. All of the above is particularly relevant in the current pandemic context, which has unexpectedly triggered the digital transformation of education.

The pedagogical shifts triggered by the digital innovations requires the transition from one dimensional learning spaces to multidimensional collaborative learning spaces. Research suggests that learners develop better learning outcomes when they are exposed to hybrid and digital learning environments (Henderson et al., 2017). For deep and meaningful learning experiences in digital age the creation of hybrid learning environments composed of socio-digital participation schemes based on digital, mobile, virtual, online, social and physical spaces is recommended (Lonka, 2015). In recent years, new actors are entering the market of education and at the same time traditional ones, such as universities, can take advantage of DT to develop new teaching and learning material (OECD, 2019b). In 2002 the Massachusetts Institute of Technology (MIT) took a paradigmatic decision: to offer formative in open online courses by means of the program OCW (Open CourseWare). MIT's decision with the favorable wind of the digital revolution, has originated a kind of tsunami in the field of transmission and accreditation of knowledge and certification of skills. The OCW has been a forerunner of open courses with mass access to quality content, the MOOCs. These are courses that offer online training very fragmented and increasingly specialized. The philosophy of MOOCs rests on the idea that knowledge should be freely shared and the learning process should not be conditioned by geographic, economic or demographic constraints.

This kind of courses have the potential to impact on higher education in two ways: improving teaching; and encouraging HEIs to develop distinctive missions that will include considerations about openness and access for different groups of students. MOOCs also provide institutions with a vehicle to think creatively and innovatively and to explore new pedagogical practices, business models and flexible learning paths in their provision (Yuan \& Powell, 2013). In addition, open courses and digital learning can make higher education more cost effective and accessible and may also contribute to balancing work, family and social life. 
However, it is argued that for online courses and digital learning in general to achieve their real potential as an effective mechanism for opening up education to society in general, and therefore working as a catalyst for change, more attention has to be paid to the multicultural nature of modern society. In this regard, three dimensions of inclusiveness should be considered: First, the varied digital literacy and competences that a student population might have; second, the socio-cultural norms that dictate how different people behave online; and third, the psychohistorical situation that reflects the varied lives of those who want to study online and how that can limit their disposition to participate in open social learning (Read \& Barcena, 2019).

\section{Digital Transformation of University Forced by Pandemics: A Study from Slovakia}

Although distance learning in the digital form has been present in HEIs for a long time, it never had such a huge auditorium as recently due to the pandemics. We can call this a "stress test" of readiness for the digital age education at all its levels. Its arrival could have been expected but not predict such a rapid onset. Adaptation to changed conditions and evaluation of a new way of education were the subject of research, which enriches the theoretical concepts of this chapter with practical outputs. In the conditions of Slovak higher education institutions, the implementation of information systems can be considered as important step in the digitization ${ }^{1}$ and informatization ${ }^{2}$ of education (including its administrative processes and communication among stakeholders).

Within the information system of university, modules developed to support e-Learning start to be extensively utilised. In addition to the administration of studies and the agenda of courses, it is mostly used for testing and examinations. Online teaching has not been so active and massively implemented in academic education. The online teaching and communication with students take place in the MS Teams environment and with the support of other Office 365 packages (Kaputa et al., 2020a, b).

\footnotetext{
${ }^{1}$ Digitization of education is a global trend in educational technologies and at the same time a logical step after the advent of the digital age. It characterizes the growth of the use of innovative technologies in society as a whole. Digital educational content involves a wider range of sensory and cognitive functions of the individual. It represents an attractive and effective form of teaching, supports clarity, connecting practical life with theoretical knowledge (Minedu.sk, 2014).

${ }^{2}$ Informatization of society is a gradual transition to the maximum use of information and communication technologies in all areas of social, political and economic life. In the field of education, introduction of the most modern information and communication technologies into the teaching process, creation of e-learning content of teaching and training of teachers for the active use of information and communication technologies in the teaching process (Minedu.sk, 2020).
} 
Table 4.1 Respondents' characteristics $(\mathrm{n}=111)$

\begin{tabular}{l|l|l|l}
\hline Sex & \multicolumn{3}{l}{ Study level } \\
\hline Men & Women & Bachelor & Master \\
\hline $34.23 \%$ & $65.77 \%$ & $37.84 \%$ & $62.16 \%$ \\
\hline
\end{tabular}

\subsection{The Research Design}

The aim is to evaluate the digital transformation of university education through the experience of students with the (unexpected) transition to distance learning. The survey brings the attitudes of students as actors of change, whose social skills predetermine employment in the labour market. Research was carried out in Slovakia at the Technical university in Zvolen (TUZVO). TUZVO is a higher education institution providing education in all three levels of studies within the European Higher Education and Research Area. In the higher education system in Slovakia, the TUZVO has a unique specialisation within a focus on the spheres of forestwood-ecology-environment with an appropriate expansion in other technical, natural, security, economics as well as design spheres (tuzvo.sk, 2020). Respondents were the university students. Designing the survey, we were interested how the students perceive online education after a year of practical experience with distance learning in order to verify whether the accelerated application of digital learning has favoured the social dimension of this innovative pedagogical method. Also, demographic data were gathered ("sex" and "academic degree" were used for analyses). We used the method of questioning. The electronic questionnaire was distributed to TUZVO students at all levels of study through the University Information System. The survey was conducted from November 2020 to January 2021. We obtained 111 questionnaires, the data of which were evaluated using contingency analysis. The Excel for Microsoft 365 and the PASW statistical software were used to process the data. The statistically significant differences of frequencies between chosen demographic characteristics of respondents and the answers were tested using Pearson chi-square. Fisher exact test was applied in cases where expected count less than 5 slightly exceeded $20 \%$ share of cells. Respondents commented on the following areas of questions: (i) Ownership and use of digital devices for school duties, (ii) Installation difficulties and user friendliness of software, and (iii) Assessment of the online education in the following sub-categories: Statements assessing online education; Improving or deteriorating of skills following the digital learning experience; Online education difficulty and requirements assessment; Online education communication assessment; and Pros and cons of online education.

\subsection{Results}

Women accounted for about two-thirds of the sample, out of a total of 111 respondents (Table 4.1). Students of master's degree programmes were represented in the sample by a larger share compared to students of bachelor's degree programmes. 
Considering hardware, notebooks (or laptops) are the most often owned digital devices $(95.5 \%)$ followed by smartphones $(72.3 \%)$. Very few university students had problems with online learning due to the lack of digital equipment suitable for connection to the educational process and fulfilment of duties. Problems were of minor importance. The most common ones were low quality of internet connection or hardware failure on students' digital devices (audio or video malfunction).

Based on the authors' own experience, students had problems to utilise more advanced features of the software used (e.g. sharing the screen, presentation of semester thesis). Overall, 59.6\% of the surveyed students handled installation and occasional technical support for online education by themselves (without any problems). However, $31.2 \%$ of students faced minor problems. $6.3 \%$ of students needed help of a friend and just $2.7 \%$ of students asked for help from university administrators. Although the frequencies of women with technical problems are more numerous, the differences (in relation to men) are not statistically significant. Most students $(61.3 \%)$ are familiar with the software used in distance education and $38.7 \%$ of students are familiar with just minor problems. None of the interviewed students need help using software for education. There is a higher share of women who have minor problems with the software user-friendliness (over 10\% in relation to men), but it is not statistically significant.

Statements about Distance Education The statements evaluating distance education show that the majority of respondents evaluate it as more flexible (up to $71.2 \%$ ), more demanding (51.2\%) and formally (just join a lecture) by students $(50.5 \%)$. Given formality is supported by other findings: (i) $38.8 \%$ of respondents agreed with the statement that teaching is faster, as students do not actively participate in the discussion, and (ii) $36.9 \%$ of respondents agreed with the statement that teaching is passive. This can also include assessments with a minimum share of agreement that online teaching is more fun, more interesting, and that students are more active in distance learning or ask more questions. On the contrary, the last two statements have one of the highest shares of respondents who disagreed. It should be added that despite the perceived formality and unattractiveness, distance education is not perceived as chaotic - up to $57.7 \%$ of respondents disagreed with the fact that it would be chaotic. In some cases (learning is: boring, more interesting, more fun, passive, and more interactive) the indifferent percentage is the highest.

Testing in the crosstabs showed statistically significant differences (Pearson Chi-Square: $10.320 ; \mathrm{p}=0.006$ ) in the proportion of men (almost $57.9 \%$ of the total number of men) agreeing that students' inactivity in online teaching makes it faster (meaning makes courses shorter) compared to the share of women $(28.8 \%)$.

The testing in crosstabs also showed statistically significant differences between the answers of bachelor's and master's students (Table 4.2):

- up to $78.6 \%$ of the total number of bachelor's do not agree with the statement that teaching is formal by teachers. None of the bachelor's students agreed, but up to $34.8 \%$ of master's students did. The difference is statistically significant (Pearson Chi-Square: $13.109 ; \mathrm{p}=0.000$ ). 
Table 4.2 Agreement with statements about distance education (share of answers in \%; $\mathrm{n}=111$ )

\begin{tabular}{l|l|l|l}
\hline \multirow{2}{*}{ Statements } & \multicolumn{3}{l}{ Answers $(\%)$} \\
\cline { 2 - 4 } & Agree & Indifferent & Disagree \\
\hline Learning is more flexible & 71.17 & 16.22 & 12.61 \\
\hline Learning is more demanding & 51.35 & 28.83 & 19.82 \\
\hline Learning is formal by students (just join a lecture) & 50.45 & 32.43 & 17.12 \\
\hline $\begin{array}{l}\text { Teaching is faster (the topic is presented in a shorter time since } \\
\text { students do not actively participate in the discussion) }\end{array}$ & 38.74 & 27.93 & 33.33 \\
\hline Learning is passive & & & \\
\hline Learning is more interactive & 36.94 & 45.05 & 18.02 \\
\hline Learning is boring & 23.42 & 45.95 & 30.63 \\
\hline Teaching is formal by teachers & 21.62 & 54.05 & 24.32 \\
\hline Learning is more effective & 21.62 & 35.14 & 43.24 \\
\hline Learning is chaotic & 21.62 & 36.94 & 41.44 \\
\hline I ask more when learning online & 17.12 & 25.23 & 57.66 \\
\hline I'm more active in online class & 10.81 & 26.13 & 63.06 \\
\hline Learning is more interesting & 9.91 & 37.84 & 52.25 \\
\hline Learning is more fun & 7.21 & 53.15 & 39.64 \\
\hline
\end{tabular}

- mainly master's students disagreed (up to $50.7 \%$ of them) with the statement that online teaching is more interesting while the attitude of bachelor's students is statistically significantly (Fisher's exact test: 10.214; $\mathrm{p}=0.004$ ) lower (disagreed $21.4 \%$ of them).

- for master's students (up to $59.4 \%$ of them), online teaching is clearly more demanding. The share of bachelor's students with such an attitude was lower (38.1\% of bachelor's students in the sample). The differences are statistically significant (Pearson Chi-Square: 6.945; $\mathrm{p}=0.031$ ).

- up to half (49.3\%) of master's students consider online education to be passive, compared to only $16.7 \%$ of bachelor's students. The difference is statistically significant (Pearson Chi-Square: 13.109; $\mathrm{p}=0.001$ ).

It should be noted that master's students have longer experience with contact learning. Moreover, the sample of bachelor's students contains more than $70 \%$ of those in the first and the second year of study, who studied mainly in the distance (online) form. Online teaching is chaotic only for $7.1 \%$ of bachelor's students. This is the statistically significant difference (Pearson Chi-Square: 9.914, $\mathrm{p}=0.006$ ) compared to $23.2 \%$ share of master's students. Regarding the fact that the quality of online teaching is not evaluated negatively by the respondents, the attitudes of those students can also be linked to the highly perceived difficulties of preparing at home for online learning (this is perceived by more than half of the respondents in the sample).

Skills Improvement or Deterioration The improvement of digital skills in $79.3 \%$ of the young people in the sample, as well as the other skills mentioned, can be considered an important factor to enter the labour market and for their professional 
Table 4.3 Assessment of skills improvement or deterioration (after online experience) $(\mathrm{n}=111)$

\begin{tabular}{l|l|l|c}
\hline \multirow{2}{*}{ Skills } & \multicolumn{3}{l}{ Answers $(\%)$} \\
\cline { 2 - 4 } & Get better & Indifferent & Get worse \\
\hline Digital skills & 79.28 & 18.02 & 2.70 \\
\hline Working with text & 70.27 & 27.93 & 1.80 \\
\hline Digital communication_Digital socialization & 68.47 & 28.83 & 2.70 \\
\hline Searching information & 64.86 & 32.43 & 2.70 \\
\hline Time management (time for work, leisure etc.) & 64.86 & 27.03 & 8.11 \\
\hline Learning on your own & 50.45 & 40.54 & 9.01 \\
\hline Processing information & 48.65 & 45.95 & 5.41 \\
\hline Detecting hoaxes and sorting information & 37.84 & 57.66 & 4.50 \\
\hline Thinking or acting creatively & 32.43 & 63.97 & 3.60 \\
\hline Problem solving and formulation & 31.53 & 60.36 & 8.11 \\
\hline Regulating own action & 18.92 & 72.97 & 8.11 \\
\hline Personal communication & 10.81 & 42.34 & 46.85 \\
\hline Formulating own opinion & 9.91 & 82.88 & 7.21 \\
\hline
\end{tabular}

growth. It is interesting to note that the online experience enhances the digital skills of all learners regardless of gender and level of education, empowering them all equally, which highlights the social dimension of digital learning (Table 4.3). The indicated improvement in working with text (70.3\% of respondents) and the ability to learn on their own (improvement in 50.5\%) should also make a positive contribution to labour integration. In the digital age of education and work, the skills of searching (improvement in $64.7 \%$ of respondents) and processing information (improvement in 48.7\%) are valuable. Procrastination is closely linked to a time when we are losing incentives to develop a diversity of activities. This is especially true in a time of pandemic, when the possibilities of alternating activities are limited and the share of time devoted to the online world is rapidly increasing. Therefore, it can be a positive finding that $64.9 \%$ of respondents reported an improvement in time management skills defined in the survey as time for work, entertainment, etc. Of course, if these activities do not take place exclusively online.

Significant shares of respondents could not clearly state whether got better or got worse (indifferent attitude) the following skills: to formulate their own opinion $(82.9 \%)$, to regulate their actions $(73.0 \%)$, to think or act creatively $(64.0 \%)$ and to formulate and solve problems $(60.4 \%)$. This clearly indicates that online education does not contribute to the ability to act independently and formulate opinions. A high share of indifferent attitudes was taken towards the ability to detect hoaxes and sort information $(57.7 \%)$. This points out that even university students are unsure in critical assessment of internet content. The development of critical thinking is thus a constant challenge for education.

The significantly higher amount of time spent online compared to the time of personal contacts (due to the pandemics) resulted in the fact that up to $46.8 \%$ of the addressed students rated the skill of personal communication as "get worse". It is 
questionable to assume to what extent is this compensated by the improvement of digital communication skills - digital socialization (68.5\% of respondents).

Analysis of the obtained data in crosstabs showed differences between respondents based on the obtained demographic characteristics. The results of the analyses point to the fact that online learning and the digitization of education did not affect different demographic groups in the same way. Statistically significant differences were found between the statements of bachelor's and master's students. As many as $69.0 \%$ of bachelor's students rated their personal communication skills as got worse. This is a significantly higher share (Pearson Chi-Square: 15,842; $p=0,000$ ) than the share of master's students (only $33.3 \%$ of them). On the other hand, a larger number of bachelor's students improved their skills during online education in the three following areas:

- Improvement in the ability to process information was reported by up to $64.3 \%$ of bachelor's students, which is significantly more (Fisher's exact test: 6.586; $\mathrm{p}=0.034)$ than the share of master's students $(39.1 \%)$.

- Improvement of the ability to work with text was reported by up to $83.3 \%$ of bachelor's students, which is significantly more (Fisher's exact test: 6.674; $\mathrm{p}=0.021)$ than master's students $(62.3 \%$ of them).

- Improvement in time management (time for work, entertainment, etc.) was reported by a significantly higher share (Fisher's exact test: $6.586 ; \mathrm{p}=0.034$ ) of bachelor's students (up to $81 \%$ of their total number) compared to master's students $(55.1 \%$ of them)

The following facts emerge from testing the differences between men's and women's responses:

- Statistically significant (Fisher's exact test: 7.250; $\mathrm{p}=0.023$ ) was the difference in how their ability to formulate their own opinion got improved. Only the women represented in the sample ( $15.1 \%$ of them) stated that they had improved in this aspect. Not a single man stated that the digital education would improve his ability to formulate his own opinion. It should be added that more than $80 \%$ of all respondents took an indifferent attitude.

- The skill of searching for information has improved in $65 \%$ of respondents, with majority of women - up to $72.6 \%$ of all women compared to $50 \%$ of all men. The difference in responses between the sexes was statistically significant (Fisher's exact test: $8.283 ; \mathrm{p}=0.009)$.

Perceived differences between men and women, as well as bachelor's and master's students, can be used in adapting the teaching process and further shaping the profile of graduates for practice.

Attributes of Distance Education Up to $52.3 \%$ of students rated the difficulty of preparing at home for online learning as higher. Others rated it mostly as standard (42.3\%) (Table 4.4).

More than half of the students rated the quality of online teaching as standard and almost $30 \%$ as higher. On the other hand, the effectiveness of online teaching 
Table 4.4 Assessment of distance education attributes (share of answers in \%; $\mathrm{n}=111$ )

\begin{tabular}{l|l|l|r}
\hline \multirow{2}{*}{ Attributes } & \multicolumn{3}{l}{ Answers (\%) } \\
\cline { 2 - 4 } & Higher & Standard & Lower \\
\hline Difficulty of preparing at home for online learning & 52.25 & 42.34 & 5.41 \\
\hline Knowledge requirements for distance education & 31.53 & 63.06 & 5.41 \\
\hline Availability of information in distance education & 30.63 & 63.06 & 6.31 \\
\hline Quality of teaching in distance education & 29.73 & 52.25 & 18.02 \\
\hline Complexity of distance education & 27.93 & 66.67 & 5.41 \\
\hline Effectiveness of online teaching compared to contact teaching & 23.42 & 36.04 & 40.54 \\
\hline
\end{tabular}

compared to contact teaching is assessed as higher by only $23.4 \%$ of students, but up to $40.5 \%$ consider the efficiency to be lower. As many as $58 \%$ of the total number of men had such an opinion. Only $31.5 \%$ of the total number of women expressed such an opinion. The difference in views between the sexes is statistically significant (Pearson Chi-Square: 7.245; $\mathrm{p}=0.030$ ). Knowledge requirements for distance education are assessed as standard by most of respondents (63.1\%). Statistically significant differences (Fisher's exact test: 9.265; $\mathrm{p}=0.006$ ) are in the attitudes of men and women, where up to $38.4 \%$ of all women (compared to $18.4 \%$ of all men) consider knowledge demands to be high.

Most respondents did not evaluate the quality of distance education negatively. Information is available to most of them in this form of education. However, its effectiveness is assessed as low by a higher share of students. In view of the above, also based on the results, it can be stated that this type of education placed increased demands on less than a third of students. This is confirmed both: by the evaluation of knowledge requirements or the evaluation of the overall complexity of distance education. But also, by the evaluation of the difficulty of preparing at home. More than half of the students perceive it as highly demanding.

Pros and Cons of Distance Education As the advantages of digital education, students most often mentioned lower costs of transport to school, faster communication, lower costs of materials to school, sufficient software and technical provision of education and others (Table 4.5). As others stated: protection from Covid-19, more time for family, more time-efficient form of education, more free time, flexibility. These results are in line with the approaches of the OECD (2019a) and the European Commission (2018), which stated that digital learning can significantly lower the cost of access to education and better meet individual needs according to their learning styles and skills.

Among the disadvantages, students mentioned the lack of personal contact with classmates, but also with teachers (whereas in some courses personal contact is irreplaceable), insufficient quality internet connection and communication (Table 4.6). Among open questions students mostly mentioned poor sound and internet quality. 
Table 4.5 Students' perception of the benefits of digital education $(n=111)$

\begin{tabular}{l|l}
\hline Statements & $\begin{array}{l}\text { Answers } \\
(\%)\end{array}$ \\
\hline Lower transport costs to school & 95.5 \\
\hline Faster communication & 61.3 \\
\hline $\begin{array}{l}\text { Lower material costs (more is required in digital form compared to contact } \\
\text { teaching) }\end{array}$ & 44.1 \\
\hline Sufficient online learning software security & 43.2 \\
\hline Sufficient technical provision of online teaching (quality computer, etc.) & 36.0 \\
\hline More time for social contacts via digital (internet) network & 24.3 \\
\hline Better learning materials for online education & 11.7 \\
\hline Greater availability of professional literature & 11.7 \\
\hline Quality internet connections & 11.7 \\
\hline Other ... & 9.9 \\
\hline $\begin{array}{l}\text { More space for discussion in the online environment than in contact teaching in } \\
\text { lectures and seminars }\end{array}$ & 4.5 \\
\hline
\end{tabular}

Table 4.6 Students' perception of the disadvantages of digital education $(\mathrm{n}=111)$

\begin{tabular}{l|l}
\hline Statements & $\begin{array}{l}\text { Answers } \\
(\%)\end{array}$ \\
\hline I lacked personal contact with classmates & 71.4 \\
\hline Unavailability of a quality internet connection & 50.0 \\
\hline $\begin{array}{l}\text { I lacked personal contact, which was necessary for some curriculum or would be } \\
\text { more suitable for explaining the curriculum }\end{array}$ & 48.2 \\
\hline $\begin{array}{l}\text { In an online environment, it is not possible to create a suitable space for discussion, } \\
\text { as is the case with contact teaching in lectures and seminars }\end{array}$ & 38.4 \\
\hline Insufficient communication & 33.9 \\
\hline Unavailability of professional literature & 27.7 \\
\hline Health problems & 19.6 \\
\hline Insufficient technical security of online teaching (quality computer, etc.) & 17.0 \\
\hline Poor quality teaching materials for online education & 11.6 \\
\hline High costs (payment for data and internet connection) & 11.6 \\
\hline Other ... & 6.3 \\
\hline Insufficient software security for online teaching & 5.4 \\
\hline I am not a technical type and therefore online teaching caused me problems & 5.4 \\
\hline &
\end{tabular}

\section{Discussion}

Do we consider DT to be a driving force for socially oriented innovation? Yes, there is an educational space where the benefits of digitization and connectivity can go far beyond boundaries of contact learning. There is a range of assistive technologies that can emphasize the potentially life-changing benefits that technology can bring to disabled people. It has the potential to make higher education more accessible as it will allow, for example, adjusting the learning material and methods to the students 
with disadvantages (AmCham, 2021). Furthermore, speakers from different cultures could be engaged to online lectures (e.g. the possibilities of the Erasmus+ platform). Online learners benefit from intercultural interactions that help to build intercultural skills. In that way, digital transformation of HEIs undoubtedly leads to social innovations as it brings new kind of knowledge, deeper experiences and expands social benefits of learners. In the research we found significant differences in perceptions and attitudes towards digital learning by gender and level of education. Taking these differences into account can contribute to the democratisation of knowledge by reducing the learning gap between different types of learners.

Societal changes require the right political decisions. The implementation of social innovations in education in Slovakia faces challenges. The Slovak Rectors' Conference (2021) considers the recently proposed investments in higher education to be insufficient given Slovakia's historical debt in the education and science and research sectors. If "further development of the Slovak Republic depends on human capital and the creation of an innovation environment", reforms and investments need to be re-evaluated in other components and in favour of higher education, science, research and innovation. The pandemic forced the implementation of social innovations in HEIs. There were focused mainly on the areas of social innovation, such as: education and human development in digital form, culture, creativity, community development and the development of technologies to increase literacy. The change from the face-to-face form of education to the distance in the online environment represents a systemic social change, aimed at eliminating the real causes of the social problems of the pandemics. This social innovation of digitalisation of education created a positive impact on education by changing the system settings, conditions, relationships between actors, rules, roles of actors to achieve better communication and education in a contactless way and by limiting personal social contacts to eliminate the spread of the virus, and transform these social contacts in the digital environment not only at the university level but also at the regional level (MIRRI SR, 2021).

The title of this chapter refers to the digital transformation as a driver of social oriented innovations. In this sense, a pandemic situation can also be considered a driver of the digital transformation of all stakeholders in education. In the environment of digital transformation, a new work and social environment is emerging, which requires new skills and professions for this generation of students (potentially proficient in connectivity, mobility, technological innovation, and flexibility). Whether the increased level of digital skills will also increase students' competencies and preconditions for a clearly better integration into the labour market is to some extent questionable. Although the sample is not representative (for the HEIs environment in Slovakia), it provides platform for reflection on the recent situation. Given the results of the survey, it will be more demanding, especially in their ability to self-motivate and in professions based on personal contact and personal communication. Long-term social isolation does not help them to build healthy selfconfidence. The recent pandemic is also a significant multiplier of the digital transformation of the university itself. It has caused the complete digitization of the students' involvement in the educational process. Immediate requirements on the 
quality of the internet connection, hardware and software equipment and the required level of digital skills were, in a sense, a small revolution in students' lives. Also teaching staff was forced to speed up the digitalization of education and linked processes and to develop new teaching and learning materialscompletely digital.

This unprecedented situation has also created an opportunity for a deeper transformation of the education system, which would reflect the needs of modern society and the future labour market better (AmCham, 2021). The labour market will challenge the technological impact, especially automation and artificial intelligence (AI) put pressure on people to be technology and IT literate. Decrease in long-term job positions caused that people would have to be more flexible. Creativity will be demanded since automatization is expected to replace a lot of routine jobs except of services relying on human touch. HEIs must accommodate all these aspects.

\section{Conclusions}

Digital transformation can be the ultimate step towards achieving specific social goals, such as opening up higher education and training professionals capable of coping with a dynamic and complex environment. The DT usually goes its own way in different spheres (public sphere, business, HEIs, etc.), but it can also have an impact on the life of whole society if the state coordinates transformation as part of a national strategy (e.g. Society 5.0 initiative in Japan).

It is obvious that teachers and students were "thrown into the water" by the immediate transformation of households into schools (insufficient technical support and not smooth connectivity). So, investing into quality IT infrastructure is the fundament of the DT for the (educational) stakeholders. The pandemic year deepened relationship of educational process with new ICT and changing contexts of society and each individual learner. The change was predictable in the academic environment (as well as in other parts of society), but no one expected such a rapid implementation of the processes leading to digitization. After a year of almost continuous distance learning since the onset of the pandemic, a survey of university students' attitudes provides insight into the consequences of this change. HEIs should strengthen the features that are less well valued and take into account the dissimilar perceptions among students of different levels and gender. They must adapt learning processes so that all students, regardless of their condition, are favoured and better prepared to face global challenges from a digital perspective. The necessary role of the university is to be a comprehensive institutional background in this rapidly established digital practice of education and take advantage of this transformation to meet social needs and create new social collaborations.

In studies of Biffi et al. (2017) and Bissola et al. (2017) is pointed out that educational networked project programs may develop managerial, behavioural and technical skills and new methods for innovation, and help students to become accustomed to accept discontinuity, conflict and diversity. The rapidly acquired 
skills of working with digital infrastructure (indicated by our research and in connection with the described theoretical concepts) are characteristic of the main actors: teachers and students. Nevertheless, not only student-teacher interaction passes through innovation, but also the wider community (which is involved, for example, through conferences, webinars, digital mobility). Our new experience confirms that online academic lectures, projects and student presentations are flexibly enriched by input from experts from other disciplines, and more often from other countries (e.g. sociologists and philosophers comment on topics of economically or technologically oriented students). This creates a strong interdisciplinary, but also international and intercultural dimension of education, so necessary for formation of students. In this way, the DT undoubtedly innovates existing processes and expands the social dimension of academic education.

The euphoria stemming from already applied and anticipated innovations of the digital era (automation and AI era) brings new questions about ethics and about how societies should be run. So, a need for good quality social sciences arises. The DT has the potential to cover all distances but may not create any proximity. Thus, social principle must be applied in any digital platform design if we want innovations to be social.

Acknowledgements This chapter is based on work from Cost Action SHIINE-Multi-disciplinary innovation for social change (CA18236) supported by COST (European Cooperation in Science and Technology), and also grant number 1/0674/19_-Proposal of a model for the eco-innovation integration into the innovation process of companies in Slovakia in order to increase their performance.

\section{References}

Abad, E., González, M. D., Infante, J. C., \& Ruipérez, G. (2020). Sustainable Management of Digital Transformation in higher education. Global research trends. Sustainability, 12. https:// doi.org/10.3390/su12052107

AmCham Slovakia. (2021). The future of education starts now. In Connection 1/2021. Available at: https://amcham.sk/publications/issues/2021-1-human-capital-education-and-labor/article/ 273441/the-future-of-education-starts-now.

Arocena, R., \& Sutz, R. A. (2017). Inclusive knowledge policies when ladders for development are hone. Some considerations on the potential role of universities. In C. Burndenius, M. Carvalho, \& B. Göransson (Eds.), Universities, inclusive development and social innovation (pp. 49-69). Springer.

Arocena, R., Göransson, B., \& Sutz, J. (2018). Developmental universities in inclusive innovation systems. Palgrave Macmillan.

Bayuo, B. B., Chaminade, C., \& Göransson, B. (2020). Unpacking the role of universities in the emergence, development and impact of social innovations- a systematic review of the literature. Technological Forecasting and Social Change, 155, 1-8.

Biffi, A., Bissola, R., \& Imperatori, B. (2017). Chasing innovation: A pilot case study of a rhizomatic design thinking education program. Education + Training, 59/9, 957-977. https:// doi.org/10.1108/ET-01-2016-0007 
Bissola, R., Imperatori, I., \& Biffi, A. (2017). A rhizomatic learning process to create collective knowledge in management education: Open innovation and collaboration beyond boundaries. Management Learning, 48(2), 206-226. https://doi.org/10.1177/1350507616672735

Brooks, C., \& McCormack, M. (2020). Driving digital transformation in higher education. ECAR research report. ECAR.

Cajaiba-Santana, G. (2014). Social innovation: moving the field forward. A conceptual framework. Technological Forecasting and Soc. Change, 82, pp. 42-51.

Castro, L. M., Tamayo, J. A., Arango, M. D., Branch, J. W., \& Burgos, D. (2020). Digital transformation in higher education institutions: A systematic literature review. Sensors, 20 (3291), 1-22.

Curaj, A., Deca, L., \& Pricopie, R. (2018). European higher education area: The impact of past and future policies. Springer.

Dawson, P., \& Daniel, L. (2010). Understanding social innovation: A provisional framework. International Journal of Technology Management, 51, 9-21.

De Pretelt, C. L., \& Hoyos, F. (2015). Innovation for social inclusion: Challenges facing the state university system in Combia. In R. T. Teranishi, L. B. Pazich, M. Knobel, \& W. Allen (Eds.), Mitigating inequality: Higher education, Resarch, policy, and practice in an era of Massification and stratification (pp. 127-147). Emerald.

EHEA. (2015). Yerevan communiqué. EHEH Ministerial Conference. Accessed Feb 25, 2021, from https://www.ehea.info/media.ehea.info/file/2015_Yerevan/70/7/YerevanCommuniqueFinal_ 613707.pdf

Elliott, G. (2013). Character and impact of social innovation in higher education. International Journal of Continuing Education and Lifelong Learning. Accessed Feb 8, 2021, from https:// eprints.worc.ac.uk/2187/2/Social_innovation__Revised_Nov_13_2012_Rex_GE_revisions_ 121118_clean.pdf

European Commission. (2013). Guide to Social Innovation. European Commission Document. https://ec.europa.eu/eip/ageing/library/guide-social-innovation_en

European Commission. (2015). The European higher education area in 2015: Bologna process implementation report. Publications Office EU. Accessed Jan 29, 2021, from https://www. eurostudent.eu/download_files/documents/2015_Implementation_report_20.05.2015.pdf

European Commission (2018). The European higher education area in 2018: Bologna process implementation report. Publication Office of the EU. Accessed Feb 9, 2021, from https://eacea. ec.europa.eu/national-policies/eurydice/sites/eurydice/files/bologna_internet_0.pdf.

Goddard, J. B., \& Chatterton, P. (1999). Regional development agencies and the knowledge economy: Harnessing the potential of universities. Environment and Planning C, 17, 685-700.

Grosseck, G., Malita, L., \& Bunoiu, M. (2020). Higher education institutions towards digital transformation-TheWUT case. In A. Curaj, L. Deca, \& R. Pricopie (Eds.), European higher education area: Challenges for a new decade (pp. 565-581). Springer.

Hazenberg, R., Wang, N., Chandra, Y., \& Nicholls, A. (2019). Surveying the social innovation and higher education landscape in Hong Kong. Brit. Council.

Henderson, M., Selwyn, N., \& Aston, R. (2017). What works and why? Student perceptions of useful digital technology in university teaching and learning. Studies in Higher Education, 42 (8), 1567-1579.

Hess, T., Matt, C., Benlian, A., \& Wiesboeck, F. (2016). Options for formulating a digital transformation strategy. MIS Quarterly Executive, 15(2), 123-139.

Hsuan-Yu, H., Feng-Hsu, L., Hung-Tai, T., \& Lu-Fui, C. (2019). Openness of technology adoption, top management support and service innovation: A social innovation perspective. Journal of Business and Industrial Marketing, 34(3), 575-590.

Jaeger, A., \& Kopper, J. (2014). Third mission potential in higher education: Measuring the regional focus of different types of HEIs. Review of Regional Research, 34(2), 95-118.

Jahnke, I., \& Kumar, S. (2014). Digital didactical designs: Teachers' integration of ipads for learning-centered processes. Journal of Digital Learning in Teacher Education, 30(3), 81-88. 
Jongbloed, B., Enders, J., \& Salermo, C. (2008). Higher education and its communities: Interconnections, interdependencies and a research agenda. Higher Education, 56(3), 303-324.

Kaputa, V., Lapin, K., Leregger, F., \& Gekic, H. (2020a). Economic dimensions of environmental citizenship. In conceptualizing environmental citizenship for 21 st century education (pp. 29-48). Springer.

Kaputa, V., Matová, H., Triznová, M., Šupín, M., \& Kalamárová, P. (2020b). Satisfaction with university information system. In Sustainability of forest-based industries in the global economy (pp. 197-200). Zagreb.

Lonka, K. (2015). Innovative schools: Teaching \& learning in the digital era. WD 1. DirectorateGeneral for Internal Policies. European Parliament. https://www.europarl.europa.eu/RegData/ etudes/STUD/2015/563389/IPOL_STU(2015)563389_EN.pdf

Loučanová, E., Olšiaková, M., \& Dzian, M. (2018). Suitability of innovative marketing communication forms in the furniture industry. Acta Facultatis Xylologiae Zvolen res Publica Slovaca, 60(1), 159-171.

Loučanová, E., \& Nosálová, M. (2020). Eco-innovation performance in Slovakia: Assessment based on ABC analysis of eco-innovation indicators. Bio Resources, 15(3), 5355-5365.

Minedu.sk. (2014). The concept of informatization and digitization of the education sector until 2020. p. 10. Available at: https://www.minedu.sk/koncepcia-informatizacie-a-digitalizacierezortu-skolstva-s-vyhladom-do-roku-2020/

Minedu.sk. (2020). Informatization and digitization of education. Available at: https://www. minedu.sk/informatizacia-a-digitalizacia-skolstva/

MIRRI SR. (2021). Ministerstvo investícií, regionálneho rozvoja a informatizácie Slovenskej republiky/Ministry of Investments, Regional Development and Informatization of the Slovak Republic. Príručka sociálnych inovácií a projektov dobrej praxe v oblasti sociálnych inovácií. Available at: https://www.mirri.gov.sk/wp-content/uploads/2021/03/Prirucka-socialnychinovacii_2021-03-31.pdf

Nadkarni, S., \& Prügl, R. (2021). Digital transformation: A review, synthesis and opportunities for future research. Management Review Quarterly, 71, 233-341.

Odabasi, H. F., Firat, M., \& Izmirli, S. (2010). Küresellesen dünyada akademisyen olmak. Anadolu Úniversitesi Sosyal Bilimler Dergisi, 10(3), 127-142.

OECD. (2019a). Going digital: Shaping policies, improving lives. OECD Publishing, . Accessed Feb 5, 2021, from 9789264312012-en.pdf

OECD. (2019b). Digital transformation and capabilities. In Supporting Entrepreneurship and Innovation in Higher Education in Italy. OECD Publishing.

Orr, D., \& Mishra, S. (2015). A comprehensive approach to investigating the social dimension in Europe-an higher education systems-EUROSTUDENT and the PL4SD country reviews. In A. Curaj, L. Matei, R. Pricopie, J. Salmi, \& P. Scott (Eds.), The European higher education area: Between critical reflections and future policies (pp. 467-478). Springer.

Orr, D., Rampelt, F., \& Knoth, A. (2020). "Bologna digital"-actively shaping the digital transformation in European higher education. In A. Curaj, L. Deca, \& R. Pricopie (Eds.), European higher education area: Challenges for a new decade (pp. 583-596). Springer.

Özbekhan, H. (1970). The Club of Rome-the Predicament of mankind: A quest for structured responses to growing world-wide complexities and uncertainties. University of Pennsylvania: Management and Behavioural Science Center.

Pavie, X., \& Carthy, D. (2015). Leveraging uncertainty: A practical approach to the integration of responsible innovation through design thinking. Procedia-social and behavioral. Sciences, 213 (1), 1040-1049.

Pol, E., \& Ville, S. (2009). Social innovation: Buzz word or enduring term? Journal of SocioEconomics, 38, 878-885.

Rampelt, F., Birnkammerer, H., Röwert, R., \& Suter, R. (2018). Opening up higher education in the digital age. Internationalisation of Higher Education, 3(D 3.1), 27-42. 
Rampelt, F., Orr, D., \& Knoth, A. (2019). Bologna digital 2020 white paper on digitalisation in the European higher education area. Research Document. Hochschulforum. Accessed Feb 5, 2021, from https://hochschulforumdigitalisierung.de/de/news/white-paper-bologna-digital-2020

Read, T., \& Barcena, E. (2019). A role for inclusive MOOCs in societal change. In G. Ubachs, L. Konings, \& B. Nijsten (Eds.), The 2019 OpenupEd trend report on MOOCs (pp. 6-9). European Association of Distance Teaching Universities (EADTU).

Reis, J., Amorim, M., Melao, N., \& Matos, P. (2018). Digital transformation: A literature review and guidelines for future research. In A. Rocha, H. Adeli, L. P. Reis, \& S. Costanzo (Eds.), Trends and advances in information systems and technologies (pp. 411-421). Springer.

Reynoso, J., Kandampully, J., Fan, X., \& Paulose, H. (2015). Learning from socially driven service innovation in emerging economies. Journal of Service Management, 26(1), 156-176.

Rittel, H. W. J., \& Webber, M. M. (1973). Dilemmas in a general theory of planning. Policy Sciences, 4, 155-169.

Rodrigues, L.S. (2017). Challenges of digital transformation in higher education institutions: A brief discussion. Proceedings of 30th IBIMA Conference.

Russo, P., \& Mueller, S. (2013). Social innovation education. In Social Innovation (pp. 171-181). Springer.

Şahin, M., \& Alkan, R. M. (2016). Yükseköğretimde değişim dönüşüm süreci ve üniversitelerin değişen rolleri. Ĕgitim ve Ö̆gretim Araştırmaları Dergisi, 5(2), 297-307.

Saykili, A. (2019). Higher education in the digital age: The impact of digital connective technologies. Journal of Educational Technology and Online Learning, 2(1), 1-15.

Schwab, K. (2016). The fourth industrial revolution: What it means, how to respond. Research Document. World Economic Forum. Accessed Feb 5, 2021, from https://www.weforum.org/ agenda/2016/01/the-fourth-industrial-revolution-what-it-means-and-how-to-respond/

Slovak Rectors' Conference. (2021). Uznesenia SRK z 98. zasadnutia (Resolutions of the SRK from the 98th session)-held on March 3, 2021. Available at: https://www.srk.sk/sk/aktuality/487uznesenia-srk-z-98-zasadnutia-konaneho-18-3-2021

Sorbonne Declaration. (1998). Joint declaration on harmonization of the architecture of the European higher education system. Sorbonne Declaration. Accessed Feb 9, 2021, from http:// www.ehea.info/media.ehea.info/file/1998_Sorbonne/61/2/

1998_Sorbonne_Declaration_English_552612.pdf

tuzvo.sk. (2020). Mission of TUZVO [online]. Available at: https://www.tuzvo.sk/en/mission

van der Have, R. P., \& Rubalcaba, L. (2016). Social innovation research: An emerging area of innovation studies? Research Policy. https://doi.org/10.1016/j.respol.2016.06.010

Vial, G. (2019). Understanding digital transformation: A review and a research agenda. Journal of Strategic Information Systems, 28, 118-144.

Yuan, L., \& Powell, S. (2013). MOOCs and disruptive innovation: Implications for higher education. eLearning Papers, 33, 1-8.

Vladislav Kaputa, $\mathrm{PhD}$ is Lecturer at the Department of Marketing, Trade and World Forestry, Technical University in Zvolen (Slovakia). He is giving lectures in International Marketing and Trade, International Management, International Economic Relations and Theory of Business. He has supervised over hundreds of bachelor and diploma's theses and run mobilities_-giving lectures at foreign universities and institutions. His research area includes broader issues of forest-based sector (analyses of stakeholders and business environment, marketing strategies, consumers' preferences), and environmental issues. He has reviewed articles for several international scientific journals and experienced professional stays at the University of Life Sciences in Poznan (the Lane Kirkland Scholarships Programme), the Kenya Forest Research Institute and some other foreign institutions. He took part in a broader scope of specialized or multidisciplinary projects either national (e.g. EU Operational Programmes) or international (e.g. COST Actions, FP7, Leonardo da Vinci, Erasmus+) and gave number of conference presentations. 
Erika Loučanová, PhD is Lecturer at the Department of Marketing, Trade and World Forestry, Technical University in Zvolen. She received a Ph.D. in Sectoral Economics-Innovative model for increasing the competitiveness of small and medium enterprises of the wood processing industry and a Ing. in wood engineering - business management. Her areas of research include the areas of innovation management, innovations, eco-innovations, innovation analyses and strategies, interactions between creators of trust in personal connections to innovative networks and clusters working on social capital and the principles of sustainability. She has authored or co-authored more publications and was involved in more domestic and international research projects including COST project.

Fernando A. Tejerina-Gaite, $\mathrm{PhD}$ is Associate Professor of Financial Economics at University of Valladolid (Spain). He has been Researcher Visiting Fellow at Leeds University Business School (UK), the University College Dublin (Ir), the Cass Business School (UK) and the University of Edinburgh (UK). His research is related to corporate governance, international business, family firms and innovation. He has earned research awards on five international organizations (University of Monterrey-Mx., JAAB-New York, Global Strategic Management Inc, European Journal of Arts and Sciences and Financial Studies Foundation). He has published several books and books chapters, and many papers in international journals such as Journal of Business Economics and Management, Journal of Business Ethics, International Business Review, Multinational Business Review, Thunderbird International Business Review, among others. He is Corresponding Editor of The Review of Business (St. John's University, NY, EEUU) and he has reviewed papers for many journals and conferences.

Open Access This chapter is licensed under the terms of the Creative Commons Attribution 4.0 International License (http://creativecommons.org/licenses/by/4.0/), which permits use, sharing, adaptation, distribution and reproduction in any medium or format, as long as you give appropriate credit to the original author(s) and the source, provide a link to the Creative Commons license and indicate if changes were made.

The images or other third party material in this chapter are included in the chapter's Creative Commons license, unless indicated otherwise in a credit line to the material. If material is not included in the chapter's Creative Commons license and your intended use is not permitted by statutory regulation or exceeds the permitted use, you will need to obtain permission directly from the copyright holder. 